\title{
African Bibliographic Center, Washington, D.C.
}

The African Bibliographic Center is introducing in 1966 a new system of information source materials in both the Special Bibliographic Series and CRLS. This new sub-series is entitled Biblio-Research and will include chronological listing of events, biographical information, and a regular charting of members of African governments. Some of this information will also be inserted in the bi-monthly $A$ Current Bibliography of African Affairs. The address of the Center is, P.O. Box 13069 , Washington, D.C. 20009, U.S.A.

\section{The African Law Center, New York}

The African Law Center was established at the end of 1965 at Columbia University with the support of a Ford Foundation grant. Its primary purpose is to encourage, direct, and undertake research into modern African law. The Center will publish the African Law Digest to provide access to African legal materials and indicate available sources of information. The Digest will cover current legal developments, particularly the legislation and subordinate legislation contained in the supplements to the official gazettes of the African nations, and has been designated the official publication of the African Law Association in America, Inc. The first issues of the Digest appeared in January and April 1966. The founder and first director of the African Law Center is Professor A. Arthur Schiller of Columbia University Law School, and the associate director Mr. Cliff F. Thompson, formerly of the University of Khartoum and Sectetary of the Sudan Law Project. The address of the Center is 435 West I I6th Street, New York, N.Y. 10027.

\section{'Littérature comparée, appliquée aux pays en voie de développement'}

M. Albert Gérard donne, à la Faculté de Philosophie et Lettres de l'Université de l'État à Liège, un cours de 'Littérature comparée, appliquée aux pays en voie de développement', qui est actuellement consacré à l'histoire des littératures négro-africaines modernes (c'està-dire écrites). Il a été invité a donner ce même enseignement au Département de Littérature Comparée de l'Université Harvard au cours du premier semestre de l'année académique 1966-7. Son programme de recherche vise à établir une histoire générale des littératures africaines modernes, qui couvrait les œuvres rédigées en langues vernaculaires aussi bien que celles qui sont rédigées dans les langues européennes.

\section{Igbo Lessons for Non-Igbo Speakers}

AN Introductory Igbo Language Course for Non-Igbo Speakers, by M. M. Green and G. E. Igwe, consists of a mimeographed and recorded course, based on a Central Igbo dialect. The book and tape are planned to be used together and may be obtained from the Methodist Missionary Society, 25 Marylebone Road, London, N.W. I. (Book I $5 s$; I 2s. 6d. to missionaries. Tape, price on application.)

A course of Igbo lessons in the Onitsha dialect, consisting of notes and tape recordings covering twenty lessons, is based on Green and Igwe's $A$ Descriptive Grammar of Igbo. Inquiries should be addressed to Mr. M. Inman, Rural Training Centre, P.O. Anwai, Asaba, Mid-West Nigeria.

1 See also Africa, xxxv, October 1965, pp. 434-5. 